\title{
The Implementation of Digital Literacy Programs at High School in Malang Raya
}

\author{
Nyimas Nadya Izana ${ }^{1}$, Dewi Puspita Rahayu ${ }^{2}$ \\ \{nyimasnadya@ub.ac.id ${ }^{1}$ \}
}

Universitas Brawijaya, Indonesia ${ }^{1,2}$

\begin{abstract}
Unwise use of the internet, such as access to pornographic content, hoax news, expressions of hatred and radicalism can result the decline of young generation's character. The government responed to these by launching the Digital Literacy Movement (DLM) in 2016. The purpose of this research is to examine the implementation of digital literacy programs at high school in Malang. This research used descriptive qualitative method with observation and interview technique. The technique of determining informants used purposive. The results show that the implementation of the digital literacy programs in Malang are not optimal. There are some students and teachers who are not familiar with these programs. They assume that digital literacy is only related to how to use digital technology and read reading material from digital media. There are students who actually think digital literacy is reading books for 15 minutes before the first hour of class begun. The implementation of digital learning is not maximally carried out yet, such as the use of edmodo, google classroom, and other digital learning media. In addition, the collection of electronic books in the library of Senior High Schools in Malang are lacking, and there are some schools that do not have any electronic book collections. Another digital literacy activity, such as hoax news prevention are also still not massive yet. The less implementation of digital literacy programs is due to the lack of program socialization, facilities, and human resources that support these programs.
\end{abstract}

Keywords: Digital Literacy, Internet, Young Generation.

\section{Introduction}

In today's digital era, the internet has become a priority need for the community. Internet has many benefits in all areas of life, such as finding news information or science, watching entertainment, playing games, shopping, getting online transportation and others. Internet can also be used to communicate through social media such as WhatsApp, Facebook, Twitter and others. This is reinforced by the data held by APJII [1] the number of internet users in 2018 was 64,8 percent around 171,17 million people from 265,16 million people in Indonesia, while in 2017 it was 54.68 percent around 143,26 millions of 262 million people. So, it can be said that the use of the internet in Indonesia increased from 2017 to 2018 around 10,12 percent with the growth of internet users in 2017-2018 was 27.916 .716 people. In addition, Indonesia also ranked third with the largest number of internet users in Asia based on Statista data and ranked fifth in the world based on internet world stats data as of March 2019 with a total users of 143.26 million or around $53 \%$ of the total Indonesian population [2][3].

Penetration of the largest internet users in Indonesia is in the age range of 15-19 years which is equal to $91 \%$, the majority of which are high school students [1]. So that the 
development of communication and information technology now takes part in changing the mindset and attitudes of adolescents. The presence of the internet changes what teenagers think and how they behave [4]. The existence of internet technology is like a-double-edge sword, there are positive and negative impacts for teenagers. According to Kirsh (2010:21) in [4] the existence of the internet can build social identities related to anxiety "who am I" and "in which group am I appropriate" [5]. Also states that the younger generation who has expertise in accessing digital media apparently has not matched their ability to obtain selfdevelopment information. This is indicated from the fact that shows that Indonesian children's access to pornographic content reaches an average of 25 thousand people per day [5]. Unhealthy internet behaviors are also shown by the spread of hoax, hate speech, and radicalism. Moreover, the development of the number of media in Indonesia reach 43,400, but there are only 243 media registered in the Press Council which result in the ease of the public in obtaining information from various existing media regardless of whether the news is official or not [5]. These things can cause a degradation in the character of the younger generation and of course become a challenge for the government as the party responsible for preparing the younger generation.

Therefore, in 2016, the government through the Ministry of Education and Culture began to activate a program called the Digital Literacy Movement (DLM) program. This program is one of six National Literacy Movement (NLM) programs consisting of reading-writing literacy, numeracy literacy, scientific literacy, financial literacy, digital literacy, and cultural \& citizenship literacy. The movement is also divided into three sections based on the target activities consisting of the School Literacy Movement (SLM), the Family Literacy Movement (FML), and the Community Literacy Movement (CLM). This movement is also an implementation of Minister of Education and Culture Regulation Number 23 of 2015 concerning the Development of Character. This digital literacy program is expected to help improve the digital literacy capabilities of adolescents who are vulnerable to exposure to irresponsible information available on the internet. Because in Indonesia, literacy is initially interpreted as 'keberaksaraan' and then interpreted as 'melek' or 'keterpahaman'. In the initial step, "melek baca dan tulis" is emphasized because these two language skills are the basis for the development of literacy in various ways. Literacy understanding in the end not only penetrate the problem of reading and writing alone, even to the stage of multiliterate [6].

The Ministry of Education and Culture also seeks to implement this digital literacy program by integrating it into the learning curriculum in schools. Research studies on digital literacy programs in schools are still lacking, the studies in general discuss more about the school literacy movement in general, not specific to digital literacy. This is reinforced by the statement of Amalia [4] that in Indonesia, digital literacy is still focused on technical competence using the internet. Many schools that teach Information and Communication Technology (ICT) education only focus on technical skills in operating computer and internet devices, for example: How to use a computer, access the internet, write online blogs, use search engines, and so on. However, there are still not many schools that also focus on teaching students the ability to communicate and participate. In addition, there was also a study conducted [7], the results of her research showed that the implementation of the school literacy movement program was carried out in stages by considering the readiness of schools throughout Indonesia. This readiness includes school capacity readiness (availability of facility, reading material, facility, literacy infrastructure), readiness of school residents, and readiness of other support systems (public participation, institutional support, and relevant policy tools). Departing from the survey on several primary school at Yogyakarta, generally, school literacy movement is still in the stage of growing the interest in reading through the 
habitual activity of reading the contexts for fifteen minutes before the lesson times. However, not all of the schools in Yogyakarta have implemented those activities. The habitual literacy can also foster the students' characteristics [7]. Hence, the question is how to implement the digital literacy in Senior High School at Malang. This sees that the School Literacy Movement $(G L S)$ is also being implemented in the Malang region, in which Malang has the predicate of Education City [8]. This study focuses on the implementation review of the GLS program especially on the digital literacy in Senior High School at Malang. This study is important to be carried out considering that there are many cases about the use of internet which are not matched by the digital literacy in younger generations that the researcher has explained before and the lack of studies on digital literacy at the Senior High School level. This study can also be an evaluation material for the implementation of digital literacy program in Malang. Therefore, the implementation of this program can be better in the future and the realization of the purpose of this program is to prepare the young generations who are literate in information and technology.

\section{Research Methods}

This study used descriptive qualitative method. The descriptive qualitative method was a research that used natural setting which aimed at describing phenomenon occurred by using words data and not in the form of numbers [9]. While according to Yusuf [10], a descriptive research was a research that focused on the problem existed in the present time or actual event by describing the situation or event precisely and accurately, not to find out the relation of cause and effect. The use of this method was chosen because to describe the implementation of digital literacy program, of which program was a new program from the government.

The data used primary and secondary data. Primary data collection was taken from the interview and observation. The interview of this study was carried out by using purposive technique, of which technique was the determination of informants with certain considerations [11]. The interview was carried out in the teachers, students, and branch of education office. Determination of students and teachers based on school location criteria which were divided into 3 areas, namely Malang City, Malang regency, and Batu City, and also school status, in which the status consisted of state and private schools. The informants in each area consisted of students and teachers in the State and Private Senior High School that categorized as favorite and non-favorite schools. The distinction of school criteria was based on the assumptions that there were differences in the education system and educational facilities based on these criteria which might affect the implementation of digital literacy program. Meanwhile, the secondary data collection came from the tracking documents related to the implementation of digital literacy program in Malang, such as activity reports, news, regulatory documents, and others. This study also used source triangulation to ensure the data validity. 


\section{Results and Discussion}

\subsection{Understanding of the Digital Literacy Program}

According to Eshet [12], the digital literacy is information literacy in a digital environment. This digital literacy refers to the technical, cognitive, and sociological skills that people needed to perform efficiently in a digital environment. The digital literacy is also defined as the interests, attitudes, and abilities of individuals in using digital technology and communication tools to access, manage, integrate, analyze, evaluate information, build new knowledge, create and communicate with others so that they could participate effectively in the community [13]. Meanwhile, the digital literacy referred to by the Ministry of Education and Culture is the knowledge and skills to use digital media, communication tools, or networks in finding out, evaluating, using, making information, and using it in a healthy, wise, intelligent, accurate, precise, and law-abiding manner in order to foster the communication and interaction in the daily life [14].

Based on the results of the study, the understanding of Senior High School students and teachers in Malang about the definition of digital literacy that had been described above was apparently still minimum. They argue that the digital literacy is only related to how to use the technology and read books in digital form (eBooks). This is actually the part of digital literacy, but it does not cover up the entirety of the benefits of this program. There is an important thing that not understood by the students and teachers of the Senior High School in Malang in understanding the digital literacy program, in which it is about how to use digital technology wisely. The wise use of digital technology is in the form of ways to evaluate and utilize the digital technology for positive things, as well as participation in disseminating useful contents/information. The knowledge about how to use digital technology wisely become an important thing in the implementation of digital literacy because it is the spearhead for overcoming problems in the form of unwise use of the internet such as accessing to pornographic videos and hoaxes.

Related to the understanding of digital literacy, in general, the Senior High School students of Malang Raya are also wrong in understanding the definition of digital literacy program. The students assume that the digital literacy is the activity of reading non-lesson books for 15 minutes before the first hour of class begin. In fact, these activities are the implementation of literacy program. The literacy program is indeed more active because this program is considered to be the basis for developing the other literacy including the digital literacy through the growing of reading interest in the students by using printed and digital books, but in the reality, the implementation was also less effective. This is also reinforced by [15] that in Indonesia, literacy is initially interpreted as 'literacy' and subsequently interpreted as 'literates' or 'understanding'. In the initial stage, "literacy" is emphasized because these two language skills are the basis for the development of literacy in various ways. Literacy understanding ultimately do not only focus on the literacy problems, but also to the stage of multi-literation.

In addition, the students generally prefer to read entertainment books such as novels and comics both in printed and electronic form, especially Wattpad and Webtoon. The understanding of digital literacy by teachers and students was important for the sustainability of this program. This is because this understanding is the basis for running this program. If the program implementers and students do not understand this program, the implementation of this program would also be less than optimal. The implementation of a digital literacy program that is less than optimal will also result in not achieving the objectives of this program. 
Because in the implementation of digital literacy in schools, it is necessary to develop the programs that integrated with the curriculum. The students need to be trained in their digital literacy skills, the teachers need to be trained to increase their creativity and the school leader's support and facilitate the digital literacy movements in schools [16].

\subsection{Implementation of Digital Literacy Program}

According to Nasrullah et al [5] the approach that can be taken on the digital literacy programs cover up two aspects, namely the conceptual and operational approaches. The conceptual approach focuses on the aspects of social cognitive and emotional development, while the operational approach focuses on the technical capabilities of the use of the media itself which cannot be ignored. In addition, Mayes and Fowler [17] also asserted the principle of developing tiered digital literacy. There are three levels of principles for developing the digital literacy according to Mayes and Fowler. First, digital competence which involves of skills, concepts, approaches, and behavior. Second, the use of digital (digital usage) that referres to the implementation of digital competencies related to a particular context. Third, digital transformation that requires the creativity and innovation in the digital world.

Approach in the implementation of the digital literacy program in Malang in general are still operational. This is due to limited application regarding the use of digital media itself through learning in ICT subject or another material that also use digital media. Meanwhile, conceptual approach that focuses on aspect of cognitive development and social emotional it has been implemented in the digital literacy program but its application still needs to be improved further. Teachers in general only give advice on the sidelines of learning about how to use digital technology, but there are no specific activities that are conceptual and practical in the implementation of this digital literacy program. Some teachers in general also do not have sufficient knowledge about this program. Hence, it is not surprising if the student's knowledge about digital literacy is also minimal because the teacher in charge of socializing the program also lacks understanding of this program. The lack of knowledge of teachers and students related to this program also becomes an obstacle in the implementation of digital literacy programs in Senior High Schools in Malang.

Meanwhile, when it viewed from the principle of developing digital literacy according to Mayes and Fowler, the implementation of digital literacy programs at the High Schools in Malang generally only covers two levels. First, digital competence that focuses on skills, concepts, approaches, and behavior. The implementation of digital literacy program at level one can be seen from several aspects such as the implementation of digital literacy program socialization, ICT lessons, multimedia lessons/extracurricular activities, and monitoring the use of digital technology in the school environment. As the researcher has explained before, the implementation of digital literacy program socialization at the local and school level is less massive and only revolves around reminding how to use digital technology wisely. In general, students are also not familiar with the term of digital literacy. The intense literacy program socialization is actually related to literacy because routine activities are carried out every day. ICT learning is also a form of digital competence development, this lesson has actually been around long before the digital literacy program was launched by the Ministry of Education and Culture. Students get knowledge about how to use digital technology through these ICT lessons. Besides through ICT lessons, students can also gain knowledge on how to use digital media practically through multimedia extracurricular lessons. Multimedia lessons are generally in vocational schools, whereas public schools are extracurricular activities. Then, the development of digital competence related to behavior is also carried out through monitoring 
the digital use of students by the teacher. Schools generally direct students to collect gadgets during class time and hold regular inspection of student gadgets. Students who are caught committing violations in the use of gadgets such as being caught having porn videos are given sanctions by the school. In addition, some schools also forbid students to carry gadgets to avoid the negative effects of using the gadget itself. It also means that digital literacy in high school equivalent students in Malang is still minimal, so schools choose not to take risks by banning students from bringing gadgets to school.

Second, digital usage is the development of digital literacy principles that are related to the practical use of digital technology in certain contexts. The development of digital literacy is based on the principle of digital usage in high schools in Malang in the form of the use of digital media in teaching and learning and other educational activities, as well as practical activities in the form of preventing the spread of hoax news. The digital media that used for learning process, such as Edmodo, Google classroom, Microsoft Power Point, and etc. There is digital learning training for teachers from both schools and education offices, but not all teachers can apply it. Teachers who do not use digital media in classroom learning are generally older generation teachers who have difficulty learning digital technology. The application of digital media by schools is in the form of providing digital libraries (Digilib), online school data collection through Basic Education Data (Dapodik), searching online literature for teaching materials, using digital information boards, using social media such as Whatsapp to spread information, and etc. Provision of digital libraries that contain electronic books (ebook) and internet access in the form of Wi-Fi are one of the important points to activate digital literacy programs. However, in reality not all schools have these facilities. Schools that generally do not have these facilities are private schools due to the obstacles in the form of lack of funds owned by schools. Then, the activity of developing digital literacy based on other digital usage principles is a workshop of prevention hoax news. Schools usually hold practitioners and academics working in this field to present material on preventing hoax news with the aim that students can avoid hoax news.

Actually, there is an equivalent high school in Malang, which is also in stage three, digital transformation, but it is still very minimal. The school in general is a school that has multimedia subjects or extracurricular. This subject really helps students to develop creativity and innovation in the digital world. The development of creativity in general through the make of creative video content which in general also contains information that is useful for the wider community. These videos are usually uploaded by students on YouTube social media and sometimes also take part in certain competitions. In addition, at the regional level there is no specific evaluation for the digital literacy program and a clear activity roadmap for the sustainability of the program. Monitoring is generally only limited to the implementation of school learning in general and the implementation of its activities is still overlapping with other literacy activities.

\section{Conclusion}

The digital literacy program is a very important because it is a solution to overcome problems that arise from the use of unwise digital technology. This program is also applied at the Senior High School in Malang. High school students are the subjects that need the most attention because they have the highest number of penetrations in internet usage. This allows them to be exposed to the negative impacts of the internet more dominant, moreover 
adolescence is a time of searching for identity. The implementation of digital literacy in Senior High Schools in Malang is still not optimal. This implementation is generally still in the form of the use of digital technology in the teaching and learning process and has not yet created a creative and innovative generation. There are several things that cause the implementation of this program to be less than optimal, namely the lack of socialization of digital literacy programs from schools and local education offices in Malang, the lack of supporting facilities such as digital libraries and internet access, and the lack of human resources who understand the program as a whole and apply it in the process classroom learning. These obstacles need to be addressed immediately so that the implementation of this program can run optimally through several things such as the provision of socialization on a massive digital literacy program, procurement of supporting facilities for digital literacy programs, increasing digital literacy activities, making clear roadmaps on digital literacy programs, and the creation of an evaluation team for digital literacy programs.

\section{References}

[1] APJII, "Infografis Penetrasi \& Profil Perilaku Pengguna Internet Indonesia," Asosiasi Penyelenggara Jasa Internet Indonesia, 2018. [Online]. Available: https://apjii.or.id/survei2018s.

[2] K. V. B, "Indonesia Pengguna Internet Terbesar Ketiga di Asia," 2019. [Online]. Available: https://databoks.katadata.co.id/datapublish/2019/07/18/indonesia-pengguna-internet-terbesarketiga-di-asia.

[3] J. D. H., "Indonesia Peringkat Kelima Dunia dalam Jumlah Pengguna Internet. Retrieved from," 2019. [Online]. Available: https://databoks.katadata.co.id/datapublish/2019/09/11/indonesiaperingkat-kelima-dunia-dalam-jumlah-pengguna-internet.

[4] R. R. Amalia, "Literasi Digital Pelajar SMA: Kemampuan Berkomunikasi dan Berpartisipasi Pelajar SMA Negeri di Daerah Istimewa Yogyakarta Melalui Internet," J. Stud. Pemuda, vol. 4, no. 1, pp. 224-240.

[5] R. Nasrullah et al., Materi Pendukung Literasi Digital. Jakarta: Kementerian Pendidikan dan Kebudayaan, 2017.

[6] P. P. B. P. dan P. B. K. P. dan Kebudayaan, Pedoman Pelaksanaan Gerakan Nasional Literasi Bangsa. Jakarta, 2016.

[7] R. T, Penumbuhan Budi Pekerti melalui Gerakan Literasi Sekolah. The Progressive and Fun Education Seminar. Muhammadiyah University Press, 2016.

[8] B. I. Publik, Malang Kota Pendidikan. 2016.

[9] L. J. Moleong, "Metodologi penelitian kualitatif (Cet. Ke-30.)," Bandung: Remaja Rosdakarya, 2012.

[10] A. M. Yusuf, Metode penelitian kuantitatif, kualitatif \& penelitian gabungan. Prenada Media, 2016.

[11] Sugiyono, Metode Penelitian Pendidikan Pendekatan Kuantitatif. Bandung: Alfabeta, 2014.

[12] Y. Eshet, "Digital literacy: A conceptual framework for survival skills in the digital era," $J$. Educ. Multimed. hypermedia, vol. 13, no. 1, pp. 93-106, 2004.

[13] J. Kurniawati and S. Baroroh, "Literasi Media Digital Mahasiswa Universitas Muhammadiyah Bengkulu," J. Komun., vol. 8, no. 2, pp. 51-66, 2016.

[14] A. G. Ibrahim and Et.al, Peta Jalan Gerakan Literasi Nasional. Jakarta: Kementrian Pendidikan dan Kebudayaan, 2017.

[15] Direktorat Jendral Pendidikan Dasar dan Menengah Kementerian Pendidikan dan Kebudayaan, Desain Induk Gerakan Literasi Sekolah. 2019.

[16] G. Rullyana, "Gerakan Literasi Digital Sebagai Gerekan Literasi Informasi di Sekolah." [Online]. Available: https://www.academia.edu/37586272/GERAKAN_LITERASI_DIGITAL_SEBAGAI_GERAK 
AN_LITERASI_INFROMASI_DI_SEKOLAH. [Accessed: 11-Nov-2019].

[17] T. Mayes and C. Fowler, "Learners, learning literacy and the pedagogy of e-learning," Digit. literacies Learn., pp. 26-33, 2006. 